\title{
GROUNDED THEORY: THE STEP-BY-STEP AND METHODOLOGICAL ISSUES IN PRACTICE
}

\author{
VANESSA M. CEPELLOS ${ }^{1}$ \\ (D) https://orcid.org/0000-0001-6707-9751 \\ MARIA JOSÉ TONELLI ${ }^{1}$ \\ (iD) https://orcid.org/0000-0002-6585-1493
}

To cite this paper: Cepellos, V. M., \& Tonelli, M. J. (2020). Grounded theory: The step-by-step and methodological issues in practice. Revista de Administração Mackenzie, 21 (5), 1-28. doi:10.1590/16786971/eRAMG200130

Submission: July 15, 2019. Acceptance: Apr. 13, 2020.

1 Fundação Getulio Vargas - Escola de Administração de Empresas de São Paulo (FGV EASP), São Paulo, SP, Brazil.

\section{(c) $\mathbf{B Y}$}

This paper may be copied, distributed, displayed, transmitted or adapted if provided, in a clear and explicit way, the name of the journal, the edition, the year and the pages on which the paper was originally published, but not suggesting that RAM endorses paper reuse. This licensing term should be made explicit in cases of reuse or distribution to third parties. It is not allowed the use for commercial purposes.

Este artigo pode ser copiado, distribuído, exibido, transmitido ou adaptado desde que citados, de forma clara e explícita, o nome da revista, a edição, o ano e as páginas nas quais o artigo foi publicado originalmente, mas sem sugerir que a RAM endosse a reutilização do artigo. Esse termo de licenciamento deve ser explicitado para os casos de reutilização ou distribuição para terceiros. Não é permitido o uso para fins comerciais. 


\section{ABSTRACT}

Purpose: This article aims to explore how the grounded theory (GT) was used in empirical research in the area of Organizational Studies. GT is a research strategy widely used in Business Administration studies both nationally and internationally. However, studies have little to do with how this research strategy is applied in practice and how researchers deal with difficulties that arise during the research process.

Originality/value: This article presents how methodological issues not provided for in the research design proposed by the GT were overcome during the data collection and analysis phases.

Design/methodology/approach: The article is based on research that aimed to understand the aging of executive women. In this article, the main codes, categories, and subcategories that emerged during the development of the field research were exposed. In addition, we present the progress of theoretical sampling and the use of specific GT techniques, such as the flip-flop technique and the progress of the research question.

Findings: As a practical implication, the article contributes to researchers who intend to use the GT, insofar they can take the step by step of using the method, as well as anticipating possible difficulties to be faced in the design of the research.

\section{KEYWORDS}

Grounded theory. Research practice. Research strategy. Aging. Women. 


\section{INTRODUCTION}

The objective of this article is to explore how methodological issues unforeseen in the research design proposed in the grounded theory (GT) were mastered during the data collection and analysis phases. It is based on research intended to understand how female executives faced their aging process (Atkinson, Ford, Harding, \& Jones, 2015; Jyrkinen \& McKie, 2012; Moore \& Radtke, 2015). The GT was chosen as the research strategy able to contribute to the construction of a theory on the theme.

The GT method came up during studies on the death process in hospitals conducted by sociologists Barney G. Glaser and Anselm L. Strauss (1968; cf. Charmaz, 2009) to develop a theory emerging from data based on categories relevant to observe core questions (Suddaby, 2006). In Business Administration researches the GT has been used in various subareas (Henwood \& Pidgeon, 2010; Goulding, 2009; Zanin, Bach, \& Walter, 2012) and problematized as to definition, limitations, and its role in the analytical process (Locke, 2015). According to Pinto, Freitas, and Mendes (2016), it takes paths where several different trends, inadequate uses, superficial treatment, and mistaken understanding of the method predominate. Based on a bibliometric study, Castro and Machado (2017) found out that, in Brazil, the methodology is not uniformly applied and hardly ever does its application result in an actual theory.

Generally speaking, studies in the Business Administration area do not inform in detail how the GT has been applied in researches, and they merely offer a brief presentation of the method and its assumptions (Ikeda \& Bacellar, 2008; Lourenço, Ferreira, \& Rosa, 2008; Saraiva, Carrieri, Aguiar, \& Brito, 2011; Pasdiora \& Brei, 2014). Although other researchers have already warned against this problem (O'Reilly, Paper, \& Marx, 2012), studies do not detail the coding process, which is core in the GT (Holton, 2007) and essential between data collection and the development of an emerging theory able to explain the data (Charmaz, 2009). Within this context, Fendt and Sachs (2008) point out the need to hold more open discussions about the challenges faced when the GT is used in order to ensure that the method meets the researcher's needs and enables quality research.

In order to contribute to that discussion, the article intends to answer the question:

- How can the coding process be developed during the GT in researches in the area of Organizational Studies, and how can the methodological issues emerging in practice be handled? 
To answer that question, in the next section, it is presented an overview of the GT; in the second section, the coding process is detailed; in the third, methodological issues and strategies for mastering them; and, at last, final considerations.

\section{THE GROUNDED THEORY METHOD}

The GT targets on developing a theory based on data systematically collected and analyzed, in which the theory emerges during the research process and becomes the product of the relation between data collection and data analysis (Goulding, 2009). The method described by Glaser and Strauss is built on two concepts: constant comparison and theoretical sampling. The former means that data are simultaneously collected and analyzed, and the latter means that the decision about the data to be collected next is determined by the theory being constructed (Suddaby, 2006). According to Morse (2016), the GT enables identifying and describing the phenomena and their main features. There are different epistemological perspectives of the GT, leading to different understandings of its conception: interpretative and critical ones and post-modern traditions (Charmaz \& Belgrave, 2012). For Charmaz (2009), no researcher is neutral; they interact with subjects' reality because the language during the codification attributes shape and meaning to the realities observed. On the other hand, the classical papers on the grounded theory written by Glaser and Strauss deal with the discovery of a theory as something that comes up from the data, isolated from the observer (Strauss \& Corbin, 2008). The objectivist GT has roots in the positivism tradition and, as such, considers the data itself to be true. Under this approach, data already exist in the world: researchers merely find them and "discover" the theory based on them. In this research, the constructivist approach was used to apply the GT based on Charmaz (2009), in which its norms respond to the interpretative tradition, far from the objectivist bases of its founders, mainly Glaser (Leite, 2015).

\subsection{The grounded theory: data collection and analysis and the coding process}

For Charmaz (2009), the coding process is composed of at least two phases: initial coding and focused coding. In the former, data fragments are studied due to their analytical importance. In-vivo codes can be used, i.e., specific expressions used by participants, which are kept in order to maintain 
the meanings related to their opinions and attitudes (Charmaz, 2009). In the latter, the material able to represent the most advantageous initial codes is selected and tested against broader data. Those codes are more directed, selective, and conceptual (Charmaz, 2009).

Strauss and Corbin (2008) refer to the initial coding as a microanalysis, which includes open and axial coding. It involves data examination and interpretation, and it includes data, observers' interpretations, and the interaction that occurs between data and researcher. During the open coding, the data are separated in different parts and compared in a search for similarities and differences. Events deemed similar are grouped under abstract concepts called "categories", i.e., concepts derived from the data which represent the phenomena which will be further developed to properties and dimensions. Properties are the characteristic of a category, and dimensions stand for the location of a property along a line.

For Strauss and Corbin (2008), the subcategories specify a category, once they denote information as to when, where, why and how a phenomenon tends to occur. Along the axial coding, the data that were divided during the open coding are regrouped. In this phase, the categories are related to their subcategories in order to generate more precise explanations. Categories can be causal conditions, intervening conditions, action/interaction strategies, or consequences (Bandeira-De-Mello \& Cunha, 2006). Charmaz (2009) understands that axial coding is a third type of coding process, which solves questions such as when, where, why, who, how and with which consequences.

During the selective coding, a process to integrate and refine theories occurs. Firstly, it is necessary to decide the central category, i.e., the category that represents the main theme of the research (Strauss \& Corbin, 2008). The circularity occurs along with the three coding phases until theoretical saturation when the gains in the theory's explicative power are approximately null (Bandeira-De-Mello \& Cunha, 2006).

Theoretical sampling is done during the research process. It is based on the concept that has come up in the analysis and which seems relevant to the theory (Strauss \& Corbin, 2008). According to Charmaz (2009), its objective is to search for and gather pertinent data to elaborate and refine the categories of the emerging theory. Theoretical sampling enables maximizing opportunities to compare facts, incidents or occurrences in order to determine how a category varies as to its properties and dimensions (Strauss \& Corbin, 2008; Charmaz, 2009). In the initial sampling, the target is to generate the maximum number of categories, and then the sampling turns to the development of those categories (Strauss \& Corbin, 2008). The core 
idea when constructing the theory is to collect data until all categories are saturated (Strauss \& Corbin, 2008).

\section{THE GROUNDED THEORY STEP-BY-STEP}

In this section, it will be presented the GT step-by-step, starting with the initial, focused and axial coding based on the interviews conducted with 58 women who worked, or had already worked as executives, and who were 40 years old or older. The first five women were contacted through the authors' contacts network, and the others were indicated by the very interviewees. The interviews were conducted along four phases, to be described next. A table with the interviewees' profile will be presented for each phase, in which they will be identified with pseudonyms in order to protect their anonymity.

\subsection{Initial coding}

\subsubsection{First phase of data collection and analysis}

In the first data collection phase, 15 interviews were conducted using a script with broad and open questions, as suggested by Charmaz (2009). For this phase, the sampling criterion used was women who perceived themselves in the aging process, i.e., self-perception of aging. During this phase, 12 women who worked in executive positions were interviewed, and three women (Cora, Leila, and Gabrielle) who had already worked in executive positions, but who had other jobs in the moment of the interview. Out of those three, one (Leila) was in the process of career change, while the other two worked as consultant and professor, as shows Figure 3.1.1.1.

(Figure 3.1.1.1)

INTERVIEWEES' PROFILE IN THE FIRST PHASE

\begin{tabular}{|c|c|c|c|}
\hline & Interviewee & Age & Position \\
\hline \multirow{4}{*}{ 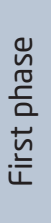 } & Rachel & 46 & Controller \\
\hline & Marion & 53 & Business owner \\
\hline & Jane & 48 & Director of strategy and operations \\
\hline & Lina & 53 & Director of strategy and operations \\
\hline
\end{tabular}

(continue) 


\section{(Figure 3.1.1.1 (conclusion))}

INTERVIEWEES' PROFILE IN THE FIRST PHASE

\begin{tabular}{|c|c|c|c|}
\hline & Interviewee & Age & Position \\
\hline \multirow{11}{*}{ 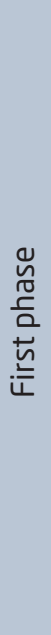 } & Cora & 60 & Independent consultant and professor \\
\hline & Virginia & 52 & Business owner \\
\hline & Clarice & 48 & Global senior vice president \\
\hline & Teresa & 53 & Manager of financial services \\
\hline & Alice & 41 & Business owner \\
\hline & Cecilia & 49 & Business owner \\
\hline & Leila & 50 & Former executive (career change) \\
\hline & Gabrielle & 53 & Independent consultant and professor \\
\hline & Aretha & 45 & Regional sales manager \\
\hline & Carmen & 54 & Executive director for the control area - Latin America \\
\hline & Tina & 53 & CEO \\
\hline
\end{tabular}

Source: Elaborated by the authors.

According to Strauss and Corbin (2008, p. 201), during the theoretical sampling, "researchers may look for people, places or facts from which they can purposely collect data related to categories, their properties and their dimensions". Generally speaking, in this first moment, the focus was to understand the background of the women interviewed, their insertion in the work market and the main difficulties faced along their career. Additionally, the intention was to identify how aging affects those women's professional and personal life. Based on the microanalysis of the data referring to this phase, 583 quotes were chosen involving 337 codes. For those purposes, a strict review of the data was conducted, which then were encoded considering their analytical importance, i.e., the codes referring to data fragments potentially able to help understanding how the interviewees' life path had happened and how the aging process affected those women's personal and professional life. This process was repeated in all phases. The main codes referring to each phase are presented in Figure 3.1.4.3 in this paper, which highlights the codes that had the highest number of quotes in ascending order.

One of the main contributions made in this first phase was redefining the research question, a common procedure that may occur during the data analysis process (Henwood \& Pidgeon, 2010). Initially, the research question to be answered was: "How does the aging process affect the personal and 
professional areas of Brazilian female executives?". But the women interviewed alleged that the personal and professional areas were not separated, as one can see in 48-year-old Clarice's speech: "Guys, there is no such thing as professional life, personal life, there is only one life. I'm one person, those things have to be integrated, they have to talk to each other". Codes such as "Type of activity", "Company's demand", "Building up a career", among others, disclose the interviewees' need to face personal and professional routines as entwined elements which can hardly be separated when considering the executive career. That is why the research question to be answered then became: "How does the aging process affect the life of Brazilian female executives?”.

Throughout the first phase, the interviewees' profile for the following phase was also redefined, another common procedure in the GT, as from the moment when data collection and analysis started (Henwood \& Pidgeon, 2010). During the interviews, it was observed that the women would refer to aging as a process that starts around 40 years of age. Thus, the sampling criterion adopted then was female executives who were 40 years old or older, i.e., what happens at around 40 years of age that determines the beginning of the aging process? This question was essential to guide the second phase of data collection and analysis. According to Strauss and Corbin (2008), a good question is one that guides researchers in a search for answers able to work for the development of a theoretical formulation.

\subsubsection{Second phase of data collection and analysis}

In the second phase, 15 women were interviewed. According to Strauss and Corbin (2008), theoretical sampling has a cumulative nature, i.e., each event sampled constructs and adds something to the previous data collection and analysis. For this phase, the sampling criterion was 40-year-old executive women or older, and women who had already worked as executives, and also women who had other professional activities. In this phase, more interviewees who had worked as executives in the past were also included in the sample but who were working as a coach, consultant or mentor in the moment of the interviews.

The reason the interviewees' profile was broadened in this phase was the identification, during the first data collection and analysis phase, of the importance of the codes: "Not to stop working" and "Redefining work", which had come up in declarations about interviewees' plans for the future. The codes identified the interviewees' intention of keeping on working during 
the aging process based on a redefinition of the work - among other reasons, due to old age. The possibility of working in other areas came up, once aging can cause disguised prejudice in the organizational environment and, should they lose their job, there is also the possibility of facing difficulties in being considered for another executive position. Therefore, the investigation during this phase of data was focused on identifying what those careers could offer to a woman referring to working conditions, and whether these careers would be related to female executives' aging process. But all of them had held executive positions before choosing new careers, as shown in Figure 3.1.2.1.

(Figure 3.1.2.1)

INTERVIEWEES' PROFILE IN THE SECOND PHASE

\begin{tabular}{|c|c|c|c|}
\hline & Interviewee & Age & Position \\
\hline \multirow{15}{*}{ 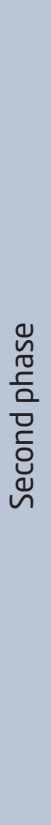 } & Nina & 49 & HR director \\
\hline & Angela & 51 & Business owner \\
\hline & Dilma & 54 & Independent coach and mentor \\
\hline & Fernanda & 59 & Regional HR director \\
\hline & Mayana & 60 & Manager of MBA \& post-graduation courses \\
\hline & Francisca & 62 & Coach and consultant \\
\hline & Valentina & 58 & Project manager \\
\hline & Rita & 54 & Former executive \\
\hline & Aída & 62 & External consultant \\
\hline & Linda & 54 & Administrative director \\
\hline & Azalea & 51 & Independent consultant \\
\hline & Diane & 55 & Independent consultant \\
\hline & Cacilda & 63 & Independent consultant and professor \\
\hline & Amelia & 46 & Independent consultant \\
\hline & Joana & 54 & Independent consultant \\
\hline
\end{tabular}

Source: Elaborated by the authors.

According to Strauss and Corbin (2008), interviewing varied subjects can help controlling analysis deviations, increasing researchers' objectivity, and identifying differences and similarities referring to the same phenomenon. So, the diversity of profiles was maintained until theoretical saturation of the topic occurred. Up to this phase, 1,012 quotes had been chosen involving 365 codes. The main codes referring to the second phase of data collection 
and analysis can be seen in Figure 3.1.4.3 herein. It was observed that, in this phase, some codes already present in the first phase kept on being relevant in the second phase, while others were replaced with new codes with more analytical importance. According to Gibbs (2009), the text should be revisited in order to check whether it is possible to encode differently by using different codes or new codes. Among the new codes, the following ones deserved highlight: "Perception of the aging process", "Personal desire", "Dissatisfaction", "Search for balance", "Search for a new career", and "Social contribution". The code "Perception of the aging process" mirrors how women recognize, or fail to recognize, themselves as older. In spite of the reference of chronological age to determine who should or should not be considered old, for the women interviewed, the perception - through physical, social, and professional aspects - of their own aging process was stressed as the main indicator of the phenomenon. Aging would then be associated with different forms of finitude. That conception is clear in the speech of Carmen, 54 .

There you are dealing with your own mind to realize that you're reaching the end of a cycle. Menopause. I'm experiencing the menopause, then the cycle of my hormonal life has ended. Even without realizing it, once I've had a lot of therapy, I say: well, is this cycle just the hormonal cycle? Am I ending a professional cycle? [...] Today I already think about mortality. And mortality comes up in different aspects, the work is over, this is a death. Hormones end, that's another death.

The other codes previously presented ("Personal desire", "Dissatisfaction", "Search for balance", "Search for a new career" and "Social contribution") complement the findings referring to redefining the career. In this phase, dissatisfaction with the executive career and the interest in searching for a new career during the aging process can be observed. Additionally, it was possible to identify the dissatisfaction with the way of working, which does not seem compatible with the moment they are living.

Based on the findings in this phase, it was possible to redefine, once again, the research question, because codes such as "Guilty feeling" "Personal desire", "Dissatisfaction", "Social contribution", "Body care", "Looks", among others, showed that the important was not necessarily how aging affects the life of female executives, but how they experience this phenomenon. The question was re-elaborated and was maintained until the end of the research: "How do female executives experience the aging process?". 
Summarizing, the second phase allowed exploring how women perceived their own aging process, the physical, social and professional aspects being the factors leading to that perception.

\subsubsection{Third phase of data collection and analysis}

In the third phase of data collection, more 15 interviews were conducted. For this phase, the sampling criterion used was 40-year-old female executives or older, and women who had already worked as executives, but currently had other professional activities or were no longer working. The flip-flop comparison technique adopted enabled us to question: "What would 'Stop working' or 'No redefinition of the career' represent for the women interviewed?". Due to that, the interviewees who had redefined their career or had stopped working were important to better understand the emerging concepts related to those topics.

Figure 3.1.3.1 presents the interviewees' profiles of this phase.

(Figure 3.1.3.1)

INTERVIEWEES' PROFILE IN THE THIRD PHASE

\begin{tabular}{|c|c|c|c|}
\hline & Interviewee & Age & Position \\
\hline \multirow{15}{*}{ 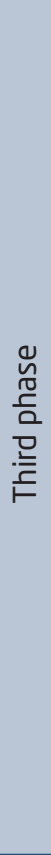 } & Agnes & 49 & Vice president \\
\hline & Ellen & 50 & Business owner \\
\hline & Patrícia & 52 & Director of coaching \& mentoring \\
\hline & Rosa & 56 & Business owner \\
\hline & Adriana & 50 & Consultant \\
\hline & Anita & 45 & Consultant and coach \\
\hline & Hilda & 44 & Chief editor \\
\hline & Marisa & 49 & Head of accounts management \\
\hline & Nara & 59 & Former executive \\
\hline & Elis & 55 & Former executive (career change) \\
\hline & Komako & 45 & Executive director \\
\hline & Nise & 58 & Business owner \\
\hline & lara & 58 & Consultant \\
\hline & Sofia & 44 & Head of marketing \\
\hline & Camille & 56 & Academic director \\
\hline
\end{tabular}

Source: Elaborated by the authors. 
In this phase, some new codes emerged and helped to improve the understanding of the phenomenon. Up to the third phase, 1,523 quotes were chosen, including 450 codes. In this phase, some codes already present in the second phase kept their relevance in the third phase, while others were replaced with new codes with higher analytical importance. The main codes referring to the third phase of data collection and analysis are presented in Figure 3.1.4.3. Some new main codes that emerged in this phase were: "Working pace", "Financial motivation", "Health", "Physical tiredness", "Perspective of a future", and "Abdication". Associated with other codes in the previous phases, these last codes helped understanding the main aspects related to the perception of the aging process and to a deeper relation between growing old and a search for redefining the work. The data suggest that the process of abdicating from social relations during their professional path had influenced the perspective of a future elaborated by female executives while aging. Therefore, it can be concluded that, in this phase, it was possible to identify aspects associated with the perspective of a future of women who, up to then, would identify their moment in life aging - as a process of physical, social and professional finitude. Then, the interest in new careers is linked to an idea of symbolic rebirth where new interests would emerge.

\subsubsection{Fourth phase of data collection and analysis}

In the fourth phase of data collection, 13 interviews were conducted with women with varied profiles. For this phase, the sampling criterion used was 40-year-old female executives or older, who had already worked as executives and who currently work in other positions and, finally, women who had already worked as executives and decided to become entrepreneurs. The only difference among the interviewees' profiles during this phase was the interviews conducted with two former executives (Carolina and Edith) who were facing the process of career change in a search for starting their own businesses, as shown in Figure 3.1.4.1.

The search for understanding the perspective of a future theoretically through entrepreneurship led us to interview an entrepreneur who had already worked as an executive. Entrepreneurship, together with other careers, stood for the possibility of a professional future for those women. At the end of the fourth phase, 1,813 quotes were selected, including 467 codes. In this phase, some codes already present in the third phase kept their relevance in the fourth phase, while others were replaced with more important new codes. The main codes referring to the fourth phase are 
presented in Figure 3.1.4.3. Some codes emerged in this phase: "Being fired", "Moment of reflection", and "Looking into oneself", which, together with other codes referring to the previous phases, suggest that aging was associated to the possibility of a professional loss, such as being fired. A significant part of female executives is afraid of being fired and face difficulties in being considered for a new position due to their age. As they see it, this means to stop having the executive identity, built up along their career. Conceiving a perspective of a future could also be deepened and it seems to be associated to the possibility of constructing a new history based on new values and expectancies.

(Figure 3.1.4.1)

INTERVIEWEES' PROFILE IN THE FOURTH PHASE

\begin{tabular}{|c|c|c|c|}
\hline & Interviewee & Age & Position \\
\hline \multirow{13}{*}{ 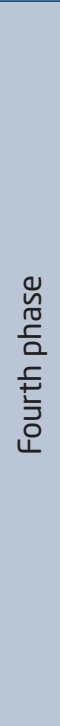 } & Marilia & 50 & Senior manager \\
\hline & Tarsila & 46 & Editor \\
\hline & Lilia & 47 & CEO \\
\hline & Carolina & 49 & Former executive/entrepreneur \\
\hline & Elizabeth & 44 & Director of global corporate communication \\
\hline & Ada & 51 & Senior consultant \\
\hline & Fabiola & 46 & Commercial director \\
\hline & Agatha & 51 & Business owner \\
\hline & Carlota & 46 & Former executive (career change) \\
\hline & Marta & 41 & Business owner \\
\hline & Marlene & 56 & Managing director \\
\hline & Edith & 42 & Former executive/entrepreneur \\
\hline & Leda & 61 & Business owner \\
\hline
\end{tabular}

Source: Elaborated by the authors.

In this phase, it was possible to deepen topics approached along the previous phases and to understand more clearly the experience of the women interviewed with the fear of being fired due to their age - one of the aspects linked to professional finitude. So, aging suggests an opportunity to look closer into themselves and at their interests, considering their path marked with a stronger dedication to the work. Here comes up a concept of symbolic rebirth, which deals with female executives' expectancies of rebuilding their histories based on new interests and values. 
Figure 3.1.4.2 shows a summary of the data collection and analysis phases as to sampling criterion, interviewees' profiles, research question, and main findings.

\section{(Figure 3.1.4.2)}

SUMMARY OF THE DATA COLLECTION AND ANALYSIS PHASES

\begin{tabular}{|c|c|c|c|c|}
\hline Phases & 1 & 2 & 3 & 4 \\
\hline $\begin{array}{l}\text { Sampling } \\
\text { criterion }\end{array}$ & $\begin{array}{l}\text { - Women who saw } \\
\text { themselves in } \\
\text { aging process. } \\
\text { - Women who had } \\
\text { already worked as } \\
\text { executives and } \\
\text { had other } \\
\text { activities at the } \\
\text { time of the } \\
\text { interview. }\end{array}$ & $\begin{array}{l}\text { - } 40 \text {-year-old } \\
\text { female executives } \\
\text { or older. } \\
\text { - Women who had } \\
\text { already worked as } \\
\text { executives and } \\
\text { worked in other } \\
\text { activities at the } \\
\text { time of the } \\
\text { interview. }\end{array}$ & $\begin{array}{l}\text { - } 40 \text {-year-old female } \\
\text { executives or older. } \\
\text { - Women who had } \\
\text { already worked as } \\
\text { executives and } \\
\text { worked in other } \\
\text { activities at the time } \\
\text { of the interview. } \\
\text { - Women who had } \\
\text { already worked as } \\
\text { executives and } \\
\text { decided to stop } \\
\text { working. }\end{array}$ & $\begin{array}{l}\text { - } 40 \text {-year-old female } \\
\text { executives or older. } \\
\text { - Women who had } \\
\text { already worked as } \\
\text { executives and } \\
\text { worked in other } \\
\text { activities at the time } \\
\text { of the interview. } \\
\text { - Women who had } \\
\text { already worked as } \\
\text { executives and } \\
\text { decided to start } \\
\text { their own business. }\end{array}$ \\
\hline $\begin{array}{l}\text { Interviewees' } \\
\text { profile }\end{array}$ & $\begin{array}{l}15 \text { interviews: } \\
\text { - } 12 \text { in executive } \\
\text { positions; } \\
\text { - two former } \\
\text { executives } \\
\text { working in other } \\
\text { activities; } \\
\text { - one in career } \\
\text { change. }\end{array}$ & $\begin{array}{l}15 \text { interviewees: } \\
\text { - seven in executive } \\
\text { positions; } \\
\text { - eight former } \\
\text { executives } \\
\text { working in other } \\
\text { activities. }\end{array}$ & $\begin{array}{l}15 \text { interviewees: } \\
\text { - } 10 \text { in executive } \\
\text { positions; } \\
\text { - four former } \\
\text { executives working } \\
\text { in other activities; } \\
\text { - one former } \\
\text { executive who } \\
\text { decided to stop } \\
\text { working. }\end{array}$ & $\begin{array}{l}13 \text { interviewees: } \\
\text { - nine in executive } \\
\text { positions; } \\
\text { - } \text { two working in other } \\
\text { activities; } \\
\text { - two former } \\
\text { executives in career } \\
\text { changes } \\
\text { (entrepreneurship). }\end{array}$ \\
\hline $\begin{array}{l}\text { Research } \\
\text { question }\end{array}$ & $\begin{array}{l}\text { How does the aging } \\
\text { process affect the } \\
\text { personal and } \\
\text { professional areas of } \\
\text { Brazilian female } \\
\text { executives? }\end{array}$ & $\begin{array}{l}\text { How does the aging } \\
\text { process affect } \\
\text { Brazilian female } \\
\text { executives' life? }\end{array}$ & $\begin{array}{l}\text { How do female } \\
\text { executives experience } \\
\text { the aging process? }\end{array}$ & $\begin{array}{l}\text { How do female } \\
\text { executives experience } \\
\text { the aging process? }\end{array}$ \\
\hline Main findings & $\begin{array}{l}\text { - Identification of } \\
\text { important points } \\
\text { characterizing the } \\
\text { female executives } \\
\text { interviewed. }\end{array}$ & $\begin{array}{l}\text { - Identification of } \\
\text { how the women } \\
\text { perceived their } \\
\text { own aging process. } \\
\text { - Identification of } \\
\text { interest in new } \\
\text { careers during the } \\
\text { aging process. }\end{array}$ & $\begin{array}{l}\text { - Identification of } \\
\text { aspects associated } \\
\text { to a perspective of a } \\
\text { future of the } \\
\text { women interviewed. }\end{array}$ & $\begin{array}{l}\text { - Deepening the } \\
\text { topics that had been } \\
\text { approached during } \\
\text { the previous phases. }\end{array}$ \\
\hline
\end{tabular}


Figure 3.1.4.3 presents a table with the main codes in each phase of the research. It can be observed that the codes that remained along the four phases were: "Traveling", "Redefining work", and "Body care".

\section{(Figure 3.1.4.3)}

CODES IN EVERY DATA COLLECTION AND ANALYSIS PHASES

\begin{tabular}{|c|c|c|c|}
\hline Phase 1 & Phase 2 & Phase 3 & Phase 4 \\
\hline Generational difference & Veiled prejudice & Working pace & Personal desire \\
\hline Male profile & $\begin{array}{l}\text { Relation with } \\
\text { youngsters }\end{array}$ & Personal desire & Sense of reference \\
\hline Maturity educates & Grown-up children & Financial motivation & Being fired \\
\hline $\begin{array}{l}\text { Glass roof is } \\
\text { psychological }\end{array}$ & Paradigm change & Business owner & Financial motivation \\
\hline Type of activity & $\begin{array}{l}\text { Perception of the aging } \\
\text { process }\end{array}$ & Health & Health \\
\hline Traveling & $\begin{array}{l}\text { Husband's role in } \\
\text { professional success }\end{array}$ & Dissatisfaction & Social contribution \\
\hline Domestic activity & Guilty feeling & Sense of reference & Moment of reflection \\
\hline Body signs & Personal desire & Search for a new career & Traveling \\
\hline Redefining work & Dissatisfaction & Grown-up children & Physical tiredness \\
\hline Business owner & Search for balance & Freedom & Grown-up children \\
\hline Feeling guilty & Search for a new career & Redefining work & Freedom \\
\hline Physical tiredness & Male universe & Traveling & Company's role \\
\hline Company's demand & Traveling & $\begin{array}{l}\text { Perception of the aging } \\
\text { process }\end{array}$ & Body care \\
\hline Paradigm change & Sense of reference & Physical tiredness & Abdication \\
\hline Veiled prejudice & Social contribution & Company's role & To be on the move \\
\hline $\begin{array}{l}\text { Difficulty at the } \\
\text { beginning of the career }\end{array}$ & Body care & Perspective of a future & Looking to oneself \\
\hline Male universe & $\begin{array}{l}\text { Gender as classification } \\
\text { criterion }\end{array}$ & Abdication & Late motherhood \\
\hline Freedom & Redefining work & Social contribution & Redefining work \\
\hline Not to stop working & Company's demand & Body care & Perspective of a future \\
\hline Body care & Company's role & Company's demand & Company's demand \\
\hline Building up the career & To be on the move & To be on the move & Search for a new career \\
\hline
\end{tabular}

Source: Elaborated by the authors. 
Based on the presentation of the four data collection and analysis phases, the GT dynamics can be observed referring to the process of theoretical sampling, how the data would lead to new investigations, how the research question would be configured based on the data, and how the new interviewees' profiles would enable understanding better how female executives experienced the aging process. In the subsection below, the focused coding will be presented.

\subsection{Focused coding}

During the focused coding, the material representing the initial codes is selected, those which enable analytical understanding in order to categorize the data (Charmaz, 2009). Out of the 467 codes identified based on the microanalysis of the data along the four data collection and analysis phases, 255 were used to explain the phenomenon studied. The selection was made based on the reflections:

- Which codes refer specifically to female executives' aging experience?

- Which codes help to understand that phenomenon?

They were selected because they were more significant and/or frequent for the purposes of elaborating the categories that would allow constructing a substantive theory. So, based on the 255 codes that seemed related to the main topic of the research, they were separated by themes considering their similarities, and a network of meanings was constructed, in which six categories and 14 subcategories were created, as shown in Figure 3.2.1.

\section{(Figure 3.2.1)}

\section{CATEGORIES AND SUBCATEGORIES}

\begin{tabular}{|c|c|c|}
\hline Category & Subcategory & Explanation \\
\hline \multirow{3}{*}{$\begin{array}{l}\text { Professional } \\
\text { background }\end{array}$} & Building up a career & \multirow{3}{*}{$\begin{array}{l}\text { The category presents the main aspects related } \\
\text { to the executive career, difficulties faced while } \\
\text { rising professionally and its consequences for } \\
\text { the women interviewed. }\end{array}$} \\
\hline & Barriers to professional rise & \\
\hline & Consequences for women & \\
\hline \multirow{2}{*}{$\begin{array}{l}\text { Daily life of a female } \\
\text { executive }\end{array}$} & Professional demands & \multirow{2}{*}{$\begin{array}{l}\text { The category encompasses the general } \\
\text { elements associated to professional and } \\
\text { personal demands determining the daily life of } \\
\text { the women interviewed. }\end{array}$} \\
\hline & Personal demands & \\
\hline
\end{tabular}




\section{(Figure 3.2.1 (conclusion))}

\section{CATEGORIES AND SUBCATEGORIES}

\begin{tabular}{|c|c|c|}
\hline Category & Subcategory & Explanation \\
\hline \multirow{2}{*}{$\begin{array}{l}\text { Experiencing ripening } \\
\text { up and maturity }\end{array}$} & $\begin{array}{l}\text { Sense of ripening up and } \\
\text { maturity }\end{array}$ & \multirow{2}{*}{$\begin{array}{l}\text { The category refers to the meanings attributed } \\
\text { to ripening up, maturity and aging, which } \\
\text { contribute, in parallel, to understand the meaning } \\
\text { of growing old for the women interviewed. }\end{array}$} \\
\hline & Sense of aging & \\
\hline \multirow{3}{*}{ Living with death } & Physical death & \multirow{3}{*}{$\begin{array}{l}\text { The category specifically demonstrates the } \\
\text { meaning attributed to aging based on the } \\
\text { conception of the announcement of physical, } \\
\text { social and professional death. These } \\
\text { perspectives determine the negative meaning of } \\
\text { decline and finitude attributed to the aging } \\
\text { process. }\end{array}$} \\
\hline & Social death & \\
\hline & Professional death & \\
\hline \multirow{2}{*}{$\begin{array}{l}\text { Resistance to the } \\
\text { aging process }\end{array}$} & Body care & \multirow{2}{*}{$\begin{array}{l}\text { The category composes the reaction of } \\
\text { resistance to the understanding of physical, } \\
\text { social and professional death of female } \\
\text { executives. The resistance takes place by means } \\
\text { of body care and the development of skills in a } \\
\text { search for compensating the effects of the } \\
\text { phenomenon. }\end{array}$} \\
\hline & $\begin{array}{l}\text { Developing personal and } \\
\text { professional skills }\end{array}$ & \\
\hline \multirow{2}{*}{ Rebirth expectancies } & Redefining work & \multirow{2}{*}{$\begin{array}{l}\text { The category proposes a possibility of a future } \\
\text { based on the redefinition of the work or end of } \\
\text { the executive career, when the women } \\
\text { interviewed face the possibility of starting over } \\
\text { a new history based on their understanding of } \\
\text { the physical, social and professional death. }\end{array}$} \\
\hline & Ending the executive career & \\
\hline
\end{tabular}

Source: Elaborated by the authors.

\subsection{Axial coding}

According to Charmaz (2009), axial coding is a third type of codification that explores questions such as: when, where, why, who, how, based on the exercise of relating categories to their subcategories in order to generate more precise explanations about the phenomenon. In this research, the subcategory "Building up the career" stands for how the "Professional background" of the female executives occurred, the subcategory "Barriers to professional rise" stands for the cause of how the "Professional background" was configured, and the subcategory "Consequences for the woman" stands for the effect caused by the "Professional background".

As to the subcategories "Professional demands" and "Personal demands", both express the causes of how the "Daily life of female executives" is charac- 
terized. The subcategories "Sense of ripening up and maturity" and "Sense of aging" stand for the causes that define the "Experience of ripening up and maturity". Meanwhile, the subcategories of "Physical death", "Social death", and "Professional death" demonstrate how the "Living with death" occurs as reported by the female executives. The subcategories "Body care" and "Developing personal and professional skills" express how "Resistance to aging" happens, while the subcategories "Redefining work" and "Ending the executive career" explain how "Rebirth expectancy" is elaborated by the women interviewed. Figure 3.3.1 illustrates those relations.

\section{(Figure 3.3.1)}

\section{RELATIONS BETWEEN CATEGORIES AND SUBCATEGORIES}

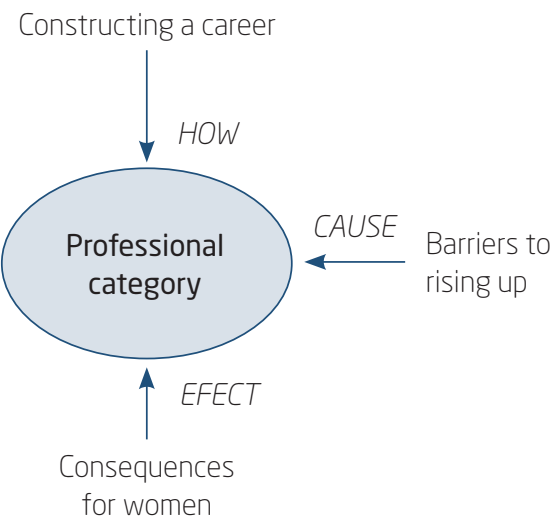

Meaning of ripening

up and maturity

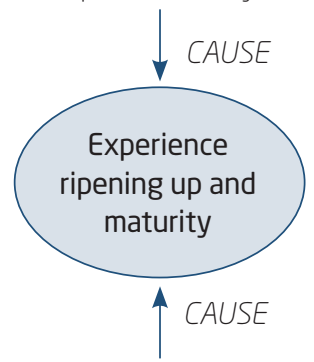

Sense of age
Caring for the body

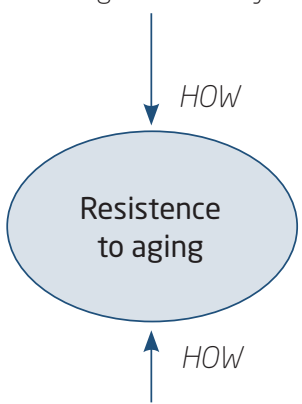

Developing personal and professional skills

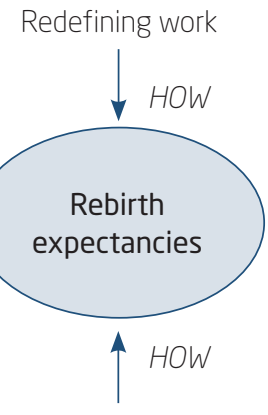

Ending the executive career

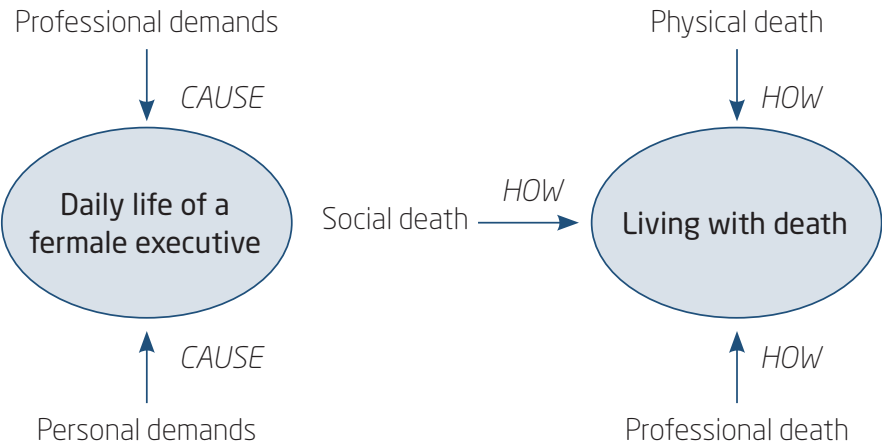

Source: Elaborated by the authors.

Strauss and Corbin (2008) recommend using a schematic table to help gathering and ordering data systematically. In this research the schematic was done as follows: 
- The categories "Professional background" and "Daily life of a female executive" allow characterizing the women interviewed and, due to that, they are deemed the conditions that create situations belonging to a phenomenon. To a certain extent, they explain why and how people respond in a certain way (Strauss \& Corbin, 2008). In this research both categories demonstrate why female executives attribute certain meaning to the aging process.

- The categories "Experiencing ripening up and maturity" and "Living with death" help understanding what growing old means to female executives, and they stand for the actions/interactions related to the topic studied. The actions/interactions are subjects' responses to questions, problems, occurrences or facts (Strauss \& Corbin, 2008). In this research, both categories include the situations and events which produce, under the conditions of the "Professional background" and "Daily life of a female executive", the meaning of growing old to the women interviewed.

- The categories "Resistance to the aging process" and "Expectancy of rebirth" transmit the reactions to the aging process and they are associated to the consequences of the actions/interactions. The consequences stand for what happens as a result of the actions/interactions or of people's failure to respond to situations by means of actions/interactions (Strauss \& Corbin, 2008). In this research, both categories represent the consequences of understanding the aging process based on the meaning that was built up on "Experiencing ripening up and maturity" and "Living with death", and they mirror ways to react to that understanding.

Such theoretical schematic enabled setting as core categories "Symbolic death" and "Rebirth in the aging process of female executives". That integration stands for the final interpretation of the data and determines how the abstraction fits the raw data.

\section{METHODOLOGICAL ISSUES}

In this section, it is presented the main methodological issues that came up while operating the GT and the strategies to handle the difficulties.

The first methodological issue found when operating the GT was to define the criterion to select the interviewees of the research, because there was no answer to the question of who could be considered a female execu- 
tive in the aging process, either due to scarce literature on the matter or to the very nature of the aging phenomenon, whose definition is complex (Kooij, De Lange, Jansen, \& Dikkers, 2008; Claes \& Heymans, 2008).

As a strategy to solve the issue of the participants' age criterion, at the beginning of the research, the aging process was analyzed based on the selfperception of the phenomenon (Sherman, 1994; Thompson, 1992; Uotinen, 2005), i.e., women who perceived they were experiencing the aging process in spite of their chronological age were interviewed. That criterion was then initially set once some experts have verified that not always does chronological age seem to be adequate to study the phenomenon (Bowling, See-Tai, Ebrahim, Gabriel, \& Solanki, 2005), and that the conception of how people feel can be more useful (Nilsson, Sarvimäki, \& Ekman, 2000). However, by giving voice to the subjects in the first interviews, they identified chronological age of 40 years old as the one that seemed more pertinent to indicate the beginning of their aging process. Therefore, said piece of information started to be used as one of the criteria when conducting the interviews.

The second methodological issue found when operating the GT was to deal with a significant number of codes, which was making it difficult to apprehend the phenomenon at each interview conducted, once the aging process is complex and diverse (Bengtson, Gans, Putney, \& Silverstein, 2009), because it is focused on the variability of the experience instead of on the universality of the phenomenon (Gans, Putney, Bengston, \& Silverstein, 2009).

To solve the methodological issue associated to the significant number of codes during codification, data collection and analysis was phased in large blocks, in order to ease understanding the aging process and to deal with the ambiguities of the very phenomenon studied. So, the initial codification occurred in four phases. The main codes that emerged during the previous phase would guide the following data collection. To do that, a script of interviews was structured for each phase based on the emerging codes. Some questions of the script used during the previous phase were kept because they were considered necessary in order to investigate better the topic explored.

The third methodological issue identified is related to the triangulation of the data collection method. Although we recognize the importance of this technique for the GT (Strauss \& Corbin, 2008; Charmaz, 2009), it could not be used due to the nature of the study object - the aging process, which is difficult to be apprehended by means of observation, documents, ethnography, among others. The aging process is a complex phenomenon that can be 
observed from different standpoints, from biological aspects to cultural aspects (Henrard, 1996).

To deal with the methodological issue associated to triangulation, the interviewees' profile was diversified (female executives who currently worked in different areas, women who searched new careers as consultants, entrepreneurs, mentors, etc.) along the four data collection and analysis phases, targeting on having different views on the aging process. This triangulation conception was inspired in one of the strategies presented by Denzin (2015), which consists of collecting data, which involves time, space and people, thus, considering the triangulation from different sources.

The fourth methodological issue identified is related to operating the flip-flop technique, which enables seeing a concept "inside out" to obtain a different perspective of a certain fact (Strauss \& Corbin, 2008). The difficulty found in using this technic was because it is necessary to compare extremes, provided that it is able to contribute to understanding the phenomenon at hand. Initially, it was considered the idea of interviewing young female executives, but it was then considered that, in the case of this research, that profile would not help understanding the aging process.

For the methodological issue linked to using the flip-flop technique accordingly to the conception of data triangulation, it was decided to keep the diversification of the interviewees' profiles, once it was understood that, although all of them had worked as female executives and were experiencing the aging process, they were working in the moment the interviews were conducted, as consultants, mentors, entrepreneurs, etc.

The fifth methodological issue identified is related to the fact that, although the GT allows setting the relations between categories and subcategories, quite often the method is rigid, thus, preventing from being considered the perceptions, impressions and nuances coming up during the researcher-subject relation during the field research. Even if that involvement is core under a constructivist standpoint (Charmaz, 2009), we do not consider that it can be easily expressed in the substantive theory. Particularly in the case of this research, the relation between a young researcher and older female executives stirred up different feelings, which remained marginal in the substantive theory, although it had certainly influenced its development.

As a strategy to face the issue of the method's rigidity, which makes it difficult to include the researcher-subject relation, it was considered that a narrative separated from the data analysis could show an interesting path for readers to understand how the researcher-participant relation occurred 
and how it influenced the substantive theory, even if those impressions had not been codified. Fendt and Sachs (2008) say that, in spite of being originally conceived as a response to positivism, the GT assumes an impartial and passive observer collecting data, but who does not participate in the creation and separation of facts and values. To overcome this limitation, we proposed a process of reflexivity (Nadin \& Cassel, 2006; Pezalla, Pettigrew, $\&$ Miller-Day, 2012) and chose to present different confessional narratives (Van Maanen, 1988), which had emerged along the research process from a sensitive theme, such as the aging process (Alcadipani \& Cepellos, 2017). Morse (2016) recognizes that the data collection strategies and the ways of preparing the data ease the theorization process, but by themselves they do not constitute a method. Additionally, Fendt and Sachs (2008) suggest reducing the GT promise of developing a substantive theory and advocate that the decision of using a method and how to use it should be shaped by the researcher's personality and experience.

\section{FINAL CONSIDERATIONS}

The GT imposes countless challenges to researchers, once it is in constant evolution (Morse, 2016). Authors advocate that, although the procedures proposed by the GT help ensuring standardization and strictness to the process, they have not been created to be dogmatically followed (Strauss \& Corbin, 2008). That flexibility results in having the methodology always used in a different way, and that happens because some researchers use only a few of the strategies proposed (Morse, 2016). However, this way of understanding the GT has been criticized by some scholars. It is said that this methodology, within the context of administration, runs the risk of losing its integrity because researchers seem to accept it as a situation when "anything goes", and they end up by using it as a generic expression to refer to any qualitative approach with a data-based inductive analysis (Jones \& Noble, 2007). Additionally, its process can be confusing, due to the complex comings and goings over time among theory, data, questions, answers and notes (Dougherty, 2017), and also because of the existence of different approaches (Alammar, Intezari, Cardow, \& Pauleen, 2019).

Those ambiguities related to the GT method raised several methodological issues while operating it, as presented in the previous section, according to the research this article was based on. Therefore, in our experience with the GT method, we found difficulties and elaborated possible exits, which 
we intend to share with future researchers. We adopted a critical stance related to the method, as did Hopfer and Maciel-Lima (2008), and we questioned ourselves:

- To what extent could we categorize and subcategorize human experience?

- To what extent does it make sense to develop a substantive theory about such particular experience as the aging process - as proposes the research on which this article is based?

Despite our attempt to present methodological strategies based on our research experience with the GT, we recognize that they are not enough to deal with the huge challenge posed by the methodology. In this sense, we invite future researchers to broaden the discussion about this matter and to report their difficulties and angsts when they decide to use the GT in their studies.

\section{GROUNDED THEORY: PASSO A PASSO E QUESTÕES METODOLÓGICAS NA PRÁTICA}

\section{RESUMO}

Objetivo: Este artigo tem como objetivo explorar como a grounded theory (GT) foi utilizada em uma pesquisa empírica na área de Estudos Organizacionais. A GT é uma estratégia de pesquisa amplamente utilizada nos estudos de Administração de Empresas, tanto nacional quanto internacionalmente. No entanto, os estudos pouco abordam como essa estratégia de pesquisa é aplicada na prática e como os pesquisadores tratam as dificuldades que surgem ao longo do processo de pesquisa.

Originalidade/valor: Este artigo apresenta como questões metodológicas não previstas no desenho de pesquisa proposto pela GT foram superadas ao longo das fases de coleta e análise de dados.

Design/metodologia/abordagem: $\mathrm{O}$ artigo tem como base uma pesquisa realizada que pretendia compreender o envelhecimento de mulheres executivas. Neste artigo, constam os principais códigos, as categorias e subcategorias que surgiram ao longo do desenvolvimento da pesquisa de campo. Além disso, apresentamos o progresso da amostragem teórica e o uso de técnicas específicas da GT, como a técnica flip-flop e o progresso da pergunta de pesquisa. 
Resultados: Como implicação prática, o artigo contribui com pesquisadores que pretendem utilizar a GT, na medida em que poderão ter o passo a passo da utilização do método, bem como antecipar possíveis dificuldades a serem enfrentadas no desenho da pesquisa.

\section{PALAVRAS-CHAVE}

Grounded theory. Pesquisa na prática. Estratégia de pesquisa. Envelhecimento. Mulheres.

\section{DEFERENCES}

Alammar, F. M., Intezari, A., Cardow, A., \& Pauleen, D. J. (2019). Grounded theory in practice: Novice researchers' choice between Straussian and Glaserian. Journal of Management Inquiry, 28(2), 228-245. doi:10.1177/ 1056492618770743

Alcadipani, R., \& Cepellos, V. (2017). Pesquisas sensíveis em Administração e Organizações: Práticas e desafios. Administração: Ensino e Pesquisa, 18(2), 421-441. Retrieved from https://raep.emnuvens.com.br/raep/article/ viewFile/680/239

Atkinson, C., Ford, J., Harding, N., \& Jones, F. (2015). The expectations and aspirations of a later-career professional woman. Work Employment \& Society, 29(6), 1019-1028. doi:10.1177/2F0950017015581987

Bandeira-De-Mello, R., \& Cunha, C. J. C. de A. (2006). Grounded theory. In C. K. Godoi, R. Bandeira-De-Mello, \& A. B. Silva (Orgs.), Pesquisa qualitativa em Estudos Organizacionais: Paradigmas, estratégias e métodos. São Paulo: Saraiva.

Bengtson, V. L., Gans, D., Putney, N. M., \& Silverstein, M. (2009). Theories about age and aging. In V. L. Bengtson, D. Gans, N. M. Putney, \& M. Silverstein (Eds.), Handbook of theories of aging (2nd ed., pp. 3-23). New York: Springer.

Bowling, A., See-Tai, S., Ebrahim, S., Gabriel, Z., \& Solanki, P. (2005). Attributes of age-identity. Ageing and Society, 25(4), 479-450. doi:10.1017/ S0144686X05003818 
Castro, A. R., \& Machado, L. (2017). Grounded theory: Uma análise da produção científica brasileira em administração no período de 2000 a 2014. Revista Alcance, 24(2), 258-271. doi:10.14210/alcance.v24n2.p258-271

Charmaz, K. (2009). A construção da teoria fundamentada: Guia prático para análise qualitativa. Porto Alegre: Artmed.

Charmaz, K., \& Belgrave, L. L. (2012). Qualitative interviewing and grounded theory analysis. In J. F. Gubrium, J. A. Holstein, A. B. Marvasti, \& K. D. McKinney (Eds.), The Sage handbook of interview research: The complexity of the craft (2nd ed., pp. 347-365). Thousand Oaks: Sage. doi:10.4135/978145 2218403

Claes, R., \& Heymans, M. (2008). HR professionals' views on work motivation and retention of older workers: A focus group study. Career Development International, 13(2), 95-11. doi:10.1108/13620430810860521

Denzin, N. K. (2015). Triangulation. In G. Ritzer (Ed.), The Blackwell Encyclopedia of Sociology. doi:10.1002/9781405165518.wbeost050.pub2

Dougherty, D. (2017). Grounded theory research methods. In J. A. Baum (Ed.), The Blackwell Companion to Organizations. doi: 10.1002/978140516 4061.ch37

Fendt, J., \& Sachs, W. (2008). Grounded theory method in management research: Users' perspectives. Organizational Research Methods, 11 (3), 430-455. doi:10.1177/2F1094428106297812

Gans, D., Putney, N. M., Bengtson, V. L., \& Silverstein, M. (2009). The future of theories of aging. In V. L. Bengtson, D. Gans, N. M, Putney, \& M. Silverstein (Eds.), Handbook of theories of aging (2nd ed., pp. 723-738). New York: Springer.

Gibbs, G. (2009). Análise de dados qualitativos. Porto Alegre: Artmed.

Glaser, B., \& Strauss, A. (1968). Time for dying. Chicago: Aldine.

Goulding, C. (2009). Grounded theory perspectives in organizational research. In D. A. Buchanan \& A. Bryman (Eds.), The Sage handbook of organizational research methods. London: Sage.

Henrard, J. C. (1996). Cultural problems of ageing especially regarding gender and intergenerational equity. Social Science and Medicine, 43(5), 667-680. doi:10.1016/0277-9536(96)00113-X

Henwood, K., \& Pidgeon, N. (2010). A teoria fundamentada. In G. M. Breakwell, C. Fife-Schaw, S. Hammond, \& J. S. Smith (Eds.), Métodos de pesquisa em psicologia (3a ed., pp. 340-361). Porto Alegre: Artmed. 
Holton, J. A. (2007). The coding process and its challenges. In A. Bryant \& K. Charmaz (Eds.), The sage handbook of grounded theory. London: Sage.

Hopfer, K. R., \& Maciel-Lima, S. M. (2008). Grounded theory: Avaliação crítica do método nos estudos organizacionais. Revista da FAE, 11 (2), 15-24. Retrieved from https://revistafae.fae.edu/revistafae/article/view/ 267

Ikeda, A. A., \& Bacellar, F. C. T. (2008). Revelando e compreendendo o relacionamento professor-aluno em marketing. Revista de Administração do Mackenzie, 9(5), 137-154. doi: 10.1590/S1678-69712008000500007

Jones, R., \& Noble, G. (2007). Grounded theory and management research: A lack of integrity? Qualitative Research in Organizations and Management, 2(2), 84-103. doi:10.1108/17465640710778502

Jyrkinen, M., \& McKie, L. (2012). Gender, age and ageism: Experiences of women managers in Finland and Scotland. Work, Employment and Society, 16(1), 61-77. doi: 10.1177/0950017011426313

Kooij, D., De Lange, A. H., Jansen, P. G. W., \& Dikkers, J. (2008). Older workers' motivation to continue work: Five meanings of age. A conceptual review. Journal of Managerial Psychology, 23(4), 364-394. doi:10.1108/ 02683940810869015

Leite, F. (2015). Raciocínio e procedimentos da grounded theory construtivista. Questões Transversais - Revista de Epistemologias da Comunicação, 3(6), 76-85. Retrieved from http://www.revistas.unisinos.br/index.php/questoes/ article/ view/11310/PDF

Locke, K. D. (2015). Pragmatic reflections on a conversation about grounded theory in Management and Organization Studies. Organizational Research Methods, 18(4), 612-619. doi:10.1177/2F1094428115574858

Lourenço, C. D. S., Ferreira, P. A., \& Rosa, A. R. (2008). Etnografia e grounded theory na pesquisa de marketing de relacionamento no mercado consumidor: Uma proposta metodológica. Revista de Administração Mackenzie, 9(4), 99-124. doi:10.1590/S1678-69712008000400007

Moore, J. A., \& Radtke, L. (2015). Starting "real" life: Women negotiating a successful midlife single identity. Psychology of Women Quarterly, 39(3), 305-319. doi: 10.1177/2F0361684315573244

Morse, J. M. (2016). Tussles, tensions and resolutions. In J. M. Morse, P. N. Stern, J. Corbin, B. Bowers, K. Charmaz, \& A. E. Clarke (Eds.), Developing grounded theory: The second generation (pp.13-22). London: Routledge.

Nadin, S., \& Cassell, C. (2006). The use of a research diary as a tool for reflexive practice: Some reflections from management research. Qualitative Research in Accounting \& Management, 3(3), 208-217. doi:10.1108/11766 090610705407 
Nilsson, M., Sarvimäki, A., \& Ekman, S. (2000). Feeling old: Being in a phase of transition in later life. Nursing Inquiry, 7(1), 41-49. doi:10.1046/ j.1440-1800.2000.00049.x

O’Reilly, K., Paper, D., \& Marx, S. (2012). Demystifying grounded theory for business research. Organizational Research Methods, 15(2), 247-262. doi:10.1177/2F1094428111434559

Pasdiora, M. A., \& Brei, V. A. (2014). A formação do hábito de consumo infantil: Uma análise crítica da teoria de consumo de status aplicada às classes sociais altas e baixas no Brasil. Organizações \& Sociedade, 21 (68), 33-58. doi:10.1590/S1984-92302014000100003

Pezalla, A. E., Pettigrew, J., \& Miller-Day, M. (2012). Researching the researcher-as-instrument: An exercise in interviewer self-reflexivity. Qualitative Research, 12(2), 165-185. doi: 10.1177/2F1468794111422107

Pinto, M. de R., Freitas, R. C., \& Mendes, C. A. F. (2016). Grounded theory in management studies in Brazil: Among the plurality of strands, improper uses and mistaken understanding? Revista Gestão \& Tecnologia, 16(1), 33-54. doi:10.20397/2177-6652/2016.v16i1.645

Saraiva, E. V., Carrieri, A. P., Aguiar, A. R. C., \& Brito, V. G. P. (2011). Um "Pas de Deux" da estratégia com a arte: As práticas do grupo Corpo de Balé. Revista de Administração Contemporânea, 15(6), 1016-1039. doi:10.1590/ S1415-65552011000600004

Sherman, S. R. (1994). Changes in age identity: Self-perceptions in middle and late life. Journal of Aging Studies, 8(4), 397-412. doi:10.1016/08904065(94)90011-6

Strauss, A., \& Corbin, J. (2008). Pesquisa qualitativa: Técnicas e procedimentos para o desenvolvimento de teoria fundamentada (2a ed.). Porto Alegre: Artmed. Suddaby, R. (2006). From the editors: What grounded theory is not. Academy of Management Journal, 49(4), 633-642. doi:10.5465/amj.2006.22083020

Thompson, P. (1992). "I don't feel old": Subjective ageing and the search for meaning in later life. Ageing and Societ, 12(1), 23-47. doi:10.1017/S0144 686 X00004657

Uotinen, V. (2005). I'm as old as I feel: Subjective age in Finnish adults (PhD thesis, University of Jyväskylä, Jyväskylä, Finland). Retrieved from https:// jyx.jyu.fi/bitstream/handle/123456789/13358/1/9513923940.pdf

Van Maanen, J. (1988). Tales of the field. Chicago: University of Chicago Press.

Zanin, E. R. M., Bach, T. M., \& Walter, S. A. (2012, outubro). Grounded theory em estudos organizacionais: Análise das metodologias, dos temas e de suas finalidades. Anais dos Seminários em Administração, São Paulo, SP, Brasil, 15. 


\section{J Wurtron Nors}

Vanessa M. Cepellos, Ph.D. from Fundação Getulio Vargas - Escola de Administração de Empresas de São Paulo (FGV EASP); Maria José Tonelli, Ph.D. from the Departament of Social Psychology, Pontifical Catholic University of São Paulo (PUC-SP).

Vanessa M. Cepellos is now professor at the FGV EASP; Maria José Tonelli is now full professor at the FGV EASP.

Correspondence concerning this article should be addressed to Vanessa M. Cepellos, Avenida Nove de Julho, 2029, $11^{\circ}$ andar, Bela Vista, São Paulo, São Paulo, Brasil, CEP 01313-902.

E-mail: vanessa.cepellos@fgv.br

\section{EDITORIAL BOARD}

Editor-in-chief

Gilberto Perez

Associated Editor

Janaina Macke

Technical support

Vitória Batista Santos Silva

\section{EDITORIAL PRODUCTION}

Publishing coordination

Jéssica Dametta

Editorial intern

Paula Di Sessa Vavlis

Language editor

Daniel de Almeida Leão
Layout designer

Emap

Graphic designer

Libro 